\title{
O IMPÉRIO E AS CELEBRAÇÕES A TIRADENTES
}

\author{
THE EMPIRE AND THE CELEBRATIONS TO TIRADENTES
}

\author{
Augusto Henrique Assis Resende ${ }^{1}$
}

\begin{abstract}
RESUMO: Neste texto, destaco alguns momentos de (re)memoração acerca da Conjuração Mineira e referentes ao mártir Tiradentes, bem como as ressignificações acerca da simbologia que envolvia o movimento setecentista mineiro ao longo de parte do século XIX. Com membros da intelectualidade nacional, marginalizados da política imperial, a buscar naquela conjura elementos que legitimassem seu acesso às esferas político-sociais do Império do Brasil. Alguns impressos mineiros servem de fonte e como fresta para se lançar luzes sobre as celebrações à memória de Tiradentes, ocorridas na década de $1880 \mathrm{em}$ muitas partes do Império, mas especificamente às grandes celebrações havidas em 1882 pelo 9. ${ }^{\circ}$ decenário do mártir mineiro, em Ouro Preto, demonstrando os usos políticos e simbólicos que se fazia da Inconfidência ainda em período monárquico.
\end{abstract}

PALAVRAS-CHAVE: Imprensa; Minas Gerais; Tiradentes.

ABSTRACT: In this text, I show some moments of rememorations about Conjuração Mineira and their martyr Tiradentes, as well as the re-significations about the symbolism that envolved the seventeenth century's conspiration of the people from Minas Gerais during part of time in the $19^{\text {th }}$ century. In a moment that some intellectuals were outsiders in the political structure of Brazil Empire, they needed use some tools that gave to them legitimacy to act in the political and social sphere. Then, some kinds of press have been used with the intention of throwing lights on celebrations of the memory about Tiradentes, that happened during the decade of 1880 in several parts of the country, specially in the year of 1882, when there was greats celebrations about the $9^{\text {th }}$ decennium of death of Tiradentes, in Ouro Preto, demonstrating the political and symbolical use of the Inconfidência still during the imperial period.

KEYWORDS: Press; Minas Gerais; Tiradentes.

\footnotetext{
* Este artigo é uma adaptação do IV capítulo de minha dissertação de mestrado, defendida na Faculdade de Ciência e Letras de Assis - UNESP, e quando de sua escrita, entre 2013 e 2014, eu tinha o fundamental e importante apoio financeiro da Fundação de Amparo à Pesquisa do Estado de São Paulo (FAPESP). Um agradecimento especial é devido ao meu orientador de então, o Prof. Dr. Claudinei Magno Magre Mendes.

1 Atualmente no doutoramento do Programa de Pós-graduação em História da Faculdade de Ciências e Letras de Assis - UNESP; bolsista CAPES desde 05/2019. Mestre em História pela mesma FCL/UNESP. Licenciado e bacharel em História pela Universidade Federal de São João del-Rei (UFSJ). Endereço eletrônico: agtassis@yahoo.com.br.
} 
A Conjuração Mineira foi um evento ocorrido na Capitania de Minas Gerais nos anos de 1788-1789 e esteve inserida em um movimento histórico bem mais amplo, decorrente das revoluções atlânticas e com repercussões ainda candentes no início do século XIX, "que destruiria o Antigo Regime e seus componentes, entre os quais, o sistema colonial mercantilista implantado em terras americanas", e que levaria à ulterior Independência brasileira (RICUPERO, 2011: 116). Relativamente à Conjuração em si há dois principais historiadores com pesquisas e resultados primorosos acerca dessa temática, são eles: Kenneth Maxwell (1978) e João Pinto Furtado (2002). As poucas páginas que se tem para elaborar um artigo com delimitação pontual de tema, como este, não abre muito espaço para tecer comentários muito abrangentes nem para análises mais aprofundadas dessas duas grandiosas obras.

Entretanto, umas poucas palavras são devidas a elas. O primeiro desses trabalhos foi elaborado nos anos 1970 pelo historiador britânico Kenneth Maxwell e foi feita uma abordagem aprofundada nos Autos de Devassa da Inconfidência Mineira. Uma das muitas questões interessantes na análise de Maxwell foi o modo como ele dividiu os conjurados mineiros em grupos de interesses. Conforme o autor, havia três níveis de apoio entre os participantes: os ativistas, os ideólogos e os financiadores. Entre os primeiros estariam os participantes de uma reunião acontecida em 26 de dezembro de 1788, onde o alferes Silva Xavier teria amplo destaque. Como profissão secundária de prático referente aos dentes, Tiradentes tinha acesso a diversas pessoas de distintas camadas sociais, contatos que poderiam ser feitos sem levantar suspeitas das autoridades. Tiradentes teria também relevantes relacionamentos com comerciantes do Rio de Janeiro, os quais poderiam ser importantes à causa inconfidente em caso de êxito. Já Cláudio Manuel da Costa, Tomás Antônio Gonzaga e Luís Vieira da Silva, seriam os representantes dos ideólogos e deveriam escrever as leis do novo Estado e elaborar uma justificativa políticaideológica para a separação ante Portugal (MAXWELL, 1978: 147-148).

O estudo de João Pinto Furtado envolveu exaustiva pesquisa das fontes da Conjuração Mineira, e em muitas circunstâncias é oposto ao de Maxwell. $O$ 
manto de Penélope (2002) consegue transmitir a dimensão de como é complexo o estudo que envolve a Conjuração, tendo em vista que há poucos vestígios e muita bibliografia referente a este movimento setecentista, sendo que em mais de uma vez alguns autores se contradizem e até fazem afirmações que as fontes não corroboram. Furtado esmiúça todos os aspectos que cercam a Inconfidência, assim como a "historiografia de referência" que abordou a temática desde o século XIX. ${ }^{2}$

Em linhas gerais, Furtado rechaça a possibilidade de a Inconfidência ter sido um movimento que visava à independência política do que hoje se delineia como o Brasil. De acordo com suas análises, se a Inconfidência não foi mais um dos tantos motins acontecidos em território mineiro ao longo do setecentos, o que os inconfidentes poderiam buscar era a emancipação da Capitania de Minas Gerais. Até a aventada união com o Rio de Janeiro e São Paulo é posta de lado pela fragilidade dos argumentos dos historiadores que defendem(iam) tal posição; e quando leva em consideração as investigações da devassa implementada pelo vice-rei Luís de Vasconcelos e Sousa, que indiciou apenas moradores da Capitania de Minas, com apenas dois da Capitania do Rio, mas inocentados ao fim do processo (FURTADO, 2002).

De maneira geral, a utilização simbólica de Joaquim José da Silva Xavier, o Tiradentes, não foi específica de um lugar, período nem meio. Durante largo espaço de tempo no século XIX, a imagem do alferes dos Dragões de Minas foi usada para diversos fins. A história de sua conjura e de seus companheiros, insatisfeitos com a exploração metropolitana portuguesa, foi ensinada em muitos compêndios de instrução do Império do Brasil, tanto na primeira como na segunda metade daquela centúria. Entretanto, é quando os partidários da república veem em Tiradentes um importante ícone de ligação entre passado, presente e futuro, pelos fins dos anos 1860, que os políticos monarquistas decidem dar mais valor e destaque à sua imagem e memória.

\footnotetext{
${ }^{2}$ João Pinto Furtado trata por historiografia de referência, em seu trabalho, os livros de Joaquim Norberto de Sousa e Silva (1873), Lúcio José dos Santos (1927), Kenneth Maxwell (1973) e Márcio Jardim (1988).
} 
Assim, de maneira a dar mais notoriedade a uma temática de bastante relevância à história nacional e que foi abordada em um dos capítulos de minha dissertação de mestrado que, em linhas gerais, trata dos usos políticos e simbólicos dos inconfidentes na imprensa de Ouro Preto e de São João del-Rei entre 1877 e 1889, este artigo foca na grande e diferenciada comemoração ocorrida na antiga capital mineira, em 1882, em decorrência dos 90 anos de morte de Tiradentes, mártir da Inconfidência e, a partir de 1890, herói nacional.

Mas antes de adentrarmos diretamente no assunto é interessante tecer alguns comentários sobre o papel social de parte dos que queriam e dos que precisavam se pautar na figura de Tiradentes para fins sociais e/ ou políticos. Pois é importante se ter em conta que o Segundo Reinado não foi um período de sossego, ao contrário, houve ali muitas situações internas de enfrentamento político, militar e religioso, além das sempre candentes demandas por reformas eleitorais efetivas e pelo federalismo.

Para complementar o momento, com a proximidade do fim da guerra contra o Paraguai, a economia nacional dava mostras de estar em bom ritmo, com ótimas colheitas de café, além de empréstimos feitos para a construção de ferrovias e investimento em urbanização, o que dava dinâmica positiva ao país. Esse momento econômico favorável atraiu muitas pessoas para as grandes cidades. Essa maior concentração populacional, incluídos nela imigrantes, ampliou o comércio e aumentou o número de atividades terciárias. Além disso, das reformas aprovadas pelo Gabinete Rio Branco (1871-1875), algumas visavam atender esses novos segmentos sociais, antes marginalizados, assim como dar oportunidades às pessoas que não tinham condições para estudar, com o aumento de escolas de instrução e técnicas, com o intuito de suprir as novas demandas econômicas do país. Contudo,

a década de 1870 teria de purgar o rescaldo do Ventre Livre, da guerra contra o Paraguai, do embate do Estado contra a Igreja, da cisão dos partidos. Ao invés de prosseguir o processo de modernização e abrir o sistema político [...] o Império fechou-se em copas (ALONSO, 2002: 93).

Com uma modernização parcial em decorrência dos enfrentamentos políticos houve dificuldades econômicas e políticas para o governo contornar 
no decorrer da guerra e após seu encerramento. Mas como a modernização da economia foi deixada de lado e muitas reformas políticas foram postergadas, os segmentos intelectuais da sociedade brasileira nos anos 1870 tiveram contato com novas e reformuladas ideologias europeias - liberalismo, cientificismo, darwinismo, etc. - das quais puderam, em algum momento, adaptar à realidade político-social brasileira. Grosso modo, o Segundo Reinado possuía uma estrutura criada na década de 1840 pelo grupo Conservador com a intenção de manter as instituições monárquicas sob seu controle, situação que ainda persistia na década de 1870. Embora até este período não houvesse, no Brasil, um grupo ou classe cuja única atividade fosse a intelectual devido às circunstâncias das políticas desenvolvidas naquele cenário político, lentamente surgia um movimento intelectual combatente dessa estrutura política (ALONSO, 2002).

De acordo com Angela Alonso, os grupos do movimento intelectual que foi denominado por ela como geração 1870 podem ser divididos em cinco tendências: liberais republicanos; novos liberais; positivistas abolicionistas; federalistas positivistas do Rio Grande do Sul; e federalistas científicos de São Paulo. Além disso, o movimento intelectual dessa geração pode ser dividido em duas correntes: a dos estudiosos que imitaram e/ou interpretaram os sistemas estrangeiros de pensamento, tendo usado esse conhecimento no campo da história das ideias, isto é, distantes da prática efetiva; e a dos estudiosos que usaram seu conhecimento para tentar atuar no campo político, ou ao menos não ficarem restritos aos seus gabinetes. Não obstante, a análise que Alonso faz acerca do movimento intelectual da geração 1870 parte da experiência desse grupo, ou seja, não se prende, portanto, à possibilidade de existirem trabalhos teóricos elaborados por esses intelectuais. Nessa perspectiva bastava se analisar a área política, já que era para lá que tudo congregava, "A base de meu argumento é um truísmo sociológico: formas de pensar estão imersas em práticas e redes sociais" (ALONSO, 2002: 38).

Com isso, o movimento intelectual da geração 1870 é classificado por Alonso como um movimento de contestação às formas estruturais do governo 
imperial. Desta feita, mais que um grupo intelectual, esse movimento poderia ser caracterizado como social, pois movimentos "intelectuais são uma modalidade de movimento social" (ALONSO, 2002: 41). Em geral, esses movimentos sociais surgem em momentos de crise política, sendo oriundos da união de interesses de um ou mais segmentos que pararam de ser beneficiados pelo poder ou então que já não o eram. Com essa situação de crise pôde ser concebida uma junção de interesses dos grupos marginalizados e uma estruturação em forma de movimento organizado.

Como as instituições políticas nacionais foram organizadas pelo grupo Conservador na derradeira década de 1840 - quando impuseram derrotas políticas e militares aos liberais em Minas Gerais, em São Paulo e em Pernambuco - suas engrenagens funcionavam de modo que beneficiavam a governança saquarema para que pudessem conduzir o sistema político sempre com avanços lentos e dentro da ordem. Os membros do movimento intelectual da geração 1870 não eram homogêneos social nem intelectualmente. Eles faziam parte de um segmento que não tinha acesso à estrutura política imperial, o Parlamento, pois não estariam inseridos na lógica nacional de poder: ser proprietários de terras e de escravos, nem conservadores. Portanto, estavam alijados de quaisquer formas institucionais do Brasil-Império. Assim,

Por sua própria condição de outsiders, os membros do movimento intelectual da geração 1870 não podiam exprimir sua crítica através das instituições políticas formais. Por esta razão, inspiraram-se no repertório de práticas contenciosas de seu tempo, desenvolvendo formas não institucionais de ação coletiva [...] O movimento intelectual não esteve voltado para um debate doutrinário alheado da realidade brasileira, nem visava formular teorias universais [...] a unidade do movimento foi política, fruto de uma experiência compartilhada de marginalização em relação aos postos de mando do Segundo Reinado [...] a produção intelectual da geração 1870 pode ser lida como uma forma de contestação política [...] Trata-se de um movimento de contestação à ordem imperial e de demanda por reformas estruturais (ALONSO, 2002: 44-45).

Ademais, as reformas postas em prática pelo Gabinete Rio Branco e que precipuamente visavam a modernização econômica do país não lograram muito 
êxito, posto que sofreram muitas restrições, tendo sido, na prática, reformas incompletas. Mas ainda assim, elas abalaram o sistema político imperial. O desgaste no partido Conservador, baqueado desde pelo menos 1862 com o desligamento de alguns de seus membros para a formação da Liga Progressista, ficou mais patente pelo programa implementado pelo Ministério Conservador. Já pelo lado dos liberais houve um ressentimento com Rio Branco por ele ter deixado de lado as reformas políticas que eles viam como as mais candentes e ter realizado uma pauta tida como secundária: o escravismo e o regime de trabalho, que era o ponto mais ousado do programa Liberal. Desse modo, essas reformas

geraram uma crise interna à elite política. Quebraram duas regras tácitas do regime. Na forma, violaram o princípio do consenso na tomada de decisões no Império, que lhes dava o caráter de responsabilidade coletiva. Substantivamente, abriram as questões indiscutíveis, a escravidão, a religião de Estado, o sistema representativo, inserindo na agenda política os fundamentos do status quo imperial (ALONSO, 2002: 87).

Mesmo que amainadas por seu sucessor, as reformas realizadas por Rio Branco abalaram muito os partidos monárquicos. Alguns de seus novos membros - que iam ao Parlamento em substituição aos políticos que participaram da consolidação monárquica - não entendiam, não se esforçavam ou pouco se importavam com a manutenção do regime da maneira que então se dava. Grosso modo, isso acontecia porque em sua maioria eram profissionais liberais que não dependiam tanto dos empregos públicos, bem como porque "A diferença geracional era politicamente relevante. Pertencendo à nova geração," esses políticos "não tinham passado pelo drama da Regência e não entendiam a preocupação dos antigos com a unidade do país" (CARVALHO, 2009: 30). As instituições saquaremas estavam cada vez mais enfraquecidas e desgastadas, o tempo havia se encarregado de torná-las obsoletas. Inclusive as denominações de conservadores e liberais perderam um pouco do sentido após tantas cisões internas nos dois partidos.

A desagregação partidária foi uma conseqüência da crise, que obrigou a redefinição do jogo de forças e redividiu a elite entre partidários e contrários das reformas [...] Desde o fim 
do mandato de Rio Branco houve contínuos reagrupamentos, com ameaças disruptivas pelo lado dos reformadores e prognósticos apocalípticos pelos emperrados (ALONSO, 2002: 90).

Nesse contexto de crise política cujas reformas de Rio Branco tiveram peso bastante considerável, houve o soerguimento dos grupos que estavam de fora das estruturas saquaremas. Com o enfraquecimento dos partidos monárquicos deu-se brecha à criação de sociedades, clubes e - em dezembro de 1870 - de um partido contrário ao regime: o partido Republicano. Independentemente do estamento a que cada grupo contestador fosse ligado, seus membros estavam afastados das instâncias políticas. Por estarem apartados da política é que criticavam as instituições imperiais. Ademais, para serem consideradas, suas críticas demandavam um repertório intelectual, posto que a estrutura estamental imperial não permitia ou ao menos dificultava um avanço em termos políticos. Então, os grupos contestadores começavam a agir de modo a deslegitimar as estruturas simbólicas imperiais. Isso se dava porque não conseguiam alcançar um lugar no Parlamento, já que as eleições geralmente eram manipuladas pelo partido que estava no poder, embora os conservadores tivessem amplo controle sobre o sistema eleitoral. Apesar disso, Alonso diz que não há porque fazer distinção entre as esferas intelectual e política no contexto final do Império, afinal, era difícil diferenciar onde uma atividade se iniciava e a outra terminava sem que houvesse uma imbricação entre elas.

Os contestadores da ordem saquarema - que pretendiam a República ou uma Monarquia mais moderada, caso dos novos liberais - começavam a atuar também nas cadeiras das escolas e das faculdades. Eles atacavam o indianismo, símbolo do intelectualismo imperial responsável pela criação da identidade nacional brasileira, fundada no início do Segundo Reinado e que dava às "raças" indígena e lusitana a proeminência da brasilidade. Eles também fundaram jornais independentes de partidos políticos e trouxeram para o Brasil uma experiência que se difundia na Inglaterra: os meetings. Na Europa e nos Estados Unidos foram buscar novidades de experiências que pudessem inserir no cotidiano brasileiro e que dessem visibilidade às suas demandas: passeatas 
públicas, comícios, banquetes, recitais e viagens de propaganda. Neste caso, para que os propagandistas pudessem falar diretamente

\begin{abstract}
à população urbana e letrada [...] a modernização técnica disseminara jornais, veículos de notícias não controlados pela elite imperial. A ampliação do público leitor forneceu ao movimento intelectual uma audiência receptiva fora do parlamento. Formava-se, assim, um pequeno espaço público, no qual o movimento intelectual desenvolveu seu proselitismo e sua performance (ALONSO, 2002: 265). ${ }^{3}$
\end{abstract}

Os grupos opositores das instituições imperiais tinham que utilizar meios alternativos que não fossem o Parlamento ou as Assembleias Provinciais para se manifestarem. Desse modo, os jornais foram uma boa opção de objeto e meio de contestação, já que por meio deles podia-se alcançar boa parte do eleitorado nacional e ainda estender suas ideias a segmentos sociais totalmente alheios à vida política do Império: caso dos homens livres pobres. Apesar da maior parte da população brasileira ser composta por analfabetos, a difusão do que era publicado na imprensa não ficava restrita a um círculo social específico. A informação contida nas folhas periódicas "perpassava amplos setores da sociedade" e "não ficava estanque a um círculo de letrados", embora seja natural pensar que estes dominassem a leitura direta dos impressos (MOREL, 2012: 25).

Aproveitando-se da liberdade de imprensa existente durante o Segundo Reinado, muitos clubes, sociedades e partidos lançaram seus jornais: dos episódicos e de pequena envergadura aos mais estáveis e de boa receptividade. O certo é que por meio da imprensa muitos homens de letras, presentes ou não no movimento intelectual da geração 1870, conseguiram um espaço para debater os rumos da política regional e nacional, expor opiniões e apresentar um lugar para a literatura por meio dos folhetins.

Essa imprensa serviu como um verdadeiro arauto dos descontentes contra o regime, pois nela os grupos contestadores apontados por Alonso tiveram espaço e ressonância para suas críticas (ALONSO, 2002). Assim sendo, vê-se que a imprensa foi um dos principais responsáveis pela divulgação das

\footnotetext{
${ }^{3}$ Grifo meu.
} 
ideias republicanas no Brasil e um excelente meio de propagação de ideais políticos contrários às instituições saquaremas, tendo em vista que as décadas de 1870 e 1880 foram períodos de bastante desenvolvimento econômico e tecnológico no país, o que facilitava a circulação de muitos jornais em várias partes do Império. A respeito disso, como comentado por Ana Luiza Martins, um desenvolvimento ainda que tardio da nossa imprensa proporcionou maior qualidade ao material impresso no Brasil na segunda metade do século XIX, em imagens e em texto (MARTINS, 2012). E com a importação de maquinário novo, como das Alauzet e Marinoni em substituição aos equipamentos mais rudimentares, ampliou-se a difusão de muitos jornais por locais antes pouco prováveis de serem alcançados.

Essa situação passa a ser demonstrada a partir de jornais de Ouro Preto que davam ensejo à difusão das alternativas políticas acima mencionadas. Desse modo, concernente ao jornal conservador ouro-pretano A Provincia de Minas, dou ênfase a três de suas edições que apresentam a programação completa do evento de comemoração em memória dos 90 anos de morte de Tiradentes. Nessas edições algumas minúcias são dadas relativamente à noite "comemorativa da gloriosa conjuração mineira", ocorrida em 23 de abril de 1882, e da festa que teve lugar na Praça da Independência, ulteriormente Praça Tiradentes. Entre os detalhes descritos, fala-se das lanternas que continham os símbolos da Conjuração: a expressão latina emprestada de Virgílio e o índio que rompia as cadeias da opressão (ambas as ideias de José Inácio de Alvarenga Peixoto para a incorporação na bandeira mineira); os nomes das Capitanias de Minas, Rio e São Paulo (estas duas que poderiam ser envolvidas ulteriormente no movimento); e poemas de autores diversos relacionados a muitos dos conjurados. No artigo jornalístico ainda se detalha o Hino de Tiradentes, composto pelo famoso poeta mineiro Bernardo Guimarães e musicado pelo maestro Emílio Horta, além da composição Sonho da Independência, também de Emílio Horta. ${ }^{4}$

\footnotetext{
${ }^{4}$ A Provincia de Minas, ano II (novo período), n. ${ }^{\circ}$ 98, 30/04/1882. Ouro Preto. P. 2. Seção Inconfidência Mineira e artigo Festa ouro-pretana.
} 
Então, com as tentativas de se resgatar a imagem de Tiradentes na década de 1870, principalmente pelos clubes republicanos das Províncias do Rio de Janeiro e de Minas Gerais, deve ser observado que foi com o início dos anos 1880 que houve sucesso na promoção da memória desse inconfidente. Deve-se ressaltar que a primeira celebração concernente ao 21 de abril aconteceu na Corte, em 1881 (CARVALHO, 2001). Conforme análise das fontes durante as pesquisas de meu mestrado, percebi que com exceção de 1880 e 1887, em todos os outros anos desse decênio houve publicações referentes aos conjurados de Minas, em especial sobre Tiradentes. Porém, 1882 teve relevância ímpar para os defensores da memória dos conjurados, pois foi o ano com mais publicações nos jornais acerca da Conjuração Mineira e de Tiradentes. Consequentemente foi o ano que mais se nota mobilizações sociais em torno do imaginário inconfidente. Toda a agitação social e política tinha um motivo plausível, visto que em 21 de abril de 1882 se completaria os 90 anos da execução do inconfidente Joaquim José da Silva Xavier.

Dos seis jornais pesquisados durante o mestrado, dois deles serão utilizados neste artigo a fim de demonstrar a importância que o 21 de Abril vinha adquirindo em Minas Gerais. Os jornais em questão são A Provincia de Minas $^{5}$ e o Liberal Mineiro, respectivamente, Conservador e Liberal, sendo ambos de Ouro Preto. Das edições 96 a 98 d'A Provincia de Minas, órgão do partido Conservador de Ouro Preto, muito se fez para a divulgação dos festejos relativos ao $9 .^{\circ}$ decenário de morte de Tiradentes. Como se vê na programação oficial:

Programa dos festejos do $9 .^{\circ}$ decenário de Tiradentes Dia 20 de abril: Espetáculo em grande gala, que começará às 8 horas da noite e logo após a chegada de S. Ex. ${ }^{a}$ o Sr. Dr. Presidente da Província por uma overtura [sic] e à grande orquestra intitulada Sonho da Independência divididas em três partes: - $1 .{ }^{\mathrm{a}}$ Prelúdios; $2 .{ }^{\mathrm{a}}$ Canto do Mártir; 3 . $^{\mathrm{a}}$ Apoteose, [...] Em seguida será cantado o Hino de Tiradentes [...] sendo a poesia do laureado poeta Bernardo Guimarães [...] Ao terminarem os discursos que serão proferidos pelos ilustrados e simpáticos oradores - Dr. Henrique Salles, Xavier da Veiga e Antonio Olyntho, como representantes da imprensa e da

\footnotetext{
${ }^{5}$ Escrito como no original, sem o acento ortográfico.
} 
comissão central, efetuar-se-á a Apoteose do Protomártir da Independência.

Dia 21 de abril: Ao romper d'alva haverá uma salva de 21 tiros no jardim da praça e será tocado o Hino de Tiradentes pela banda marcial do corpo policial, que em seguida percorrerá as ruas da capital. [...]

Dia 22 de abril: Às 8 horas da noite será levado à cena, pela 2. ${ }^{a}$ vez, o mesmo drama Abençoadas Lágrimas! Procedido da overtura $[\mathrm{sic}]$ - Sonho da Independência $\left[\ldots . .{ }^{6}\right.$

Em nota após o programa, a comissão responsável pelo evento esclarecia que havia tido poucos recursos financeiros frente às grandes despesas e pedia que o público comparecesse às peças teatrais como uma forma de ajudar financeiramente. Além disso, ressaltava o convite para que a população participasse da conferência que se realizaria no teatro da capital.

No editorial do número 97 o autor defendia a utilização simbólica dos inconfidentes por qualquer partido político, independentemente de sua orientação. Além de descrever todas as atividades concernentes à comemoração do 21 de abril, ele destacava também a importância dos conjurados mineiros para a história nacional, mas principalmente para a história dos mineiros:

Desde a noite do dia 20 do corrente até a de ontem, a população ouro-pretana, em atos sucessivos e imponentes, manifestou bela e eloquentemente os sentimentos patrióticos que a amimam para com os vultos legendários da história pátria, precursores ilustres da liberdade e da independência nacional.

O objeto das entusiásticas manifestações foi a comemoração do 9..$^{\circ}$ decenário de Tiradentes, coração e alma da nobre e malograda inconfidência mineira, o mais ardente de seus adeptos e o mais glorioso de seus mártires.

Sem distinção de classes e matizes políticos - todos se associaram no elevado pensamento da patriótica comemoração.

Assim deve ser. A conjuração mineira de 1789 não reflete o exclusivismo de uma escola partidária, como a alguns espíritos menos refletidos se afigura.

Sua bandeira foi a da - Independência e da Liberdade - e a bandeira da pátria, sob cuja sombra protetora se acolhem todos bons cidadãos. Tiradentes, Cláudio Manoel, Gonzaga [...] e tantos outros beneméritos propugnadores do movimento emancipador só ambicionavam, quebrando o

\footnotetext{
${ }^{6}$ A Provincia de Minas, ano II (novo período), n. ${ }^{\circ}$ 96, 16/04/1882, Ouro Preto. P. 4. Ortografia atualizada, embora eu tenha alterado um pouco a forma com que o texto foi montado, com o original tendo boa parte centralizado, com título e subtítulos.
} 
[SIC] grilhões da escravidão colonial, construir para si e para seus conterrâneos uma pátria livre e independente.

Liberdade e independência não são privilégios exclusivos de nenhum regime político [...]. A memória dos patriotas mineiros de 1789 é e merece ser venerada por todos os homens livres, quaisquer que sejam as escolas políticas a que se filiem $[\ldots]^{7}$

Foi sublinhada a participação popular nos três dias de evento, sendo dito que houvera grande concorrência do público para todos eles. É interessante que além da participação das variadas classes sociais foi salientado que o Estado também se fazia presente nas festividades, não só pelos altos funcionários, mas especialmente pela presença de Teófilo Otoni (filho), presidente da Província. A participação de membros destacados do Estado mineiro nas comemorações concernentes aos inconfidentes, e principalmente ao alferes Silva Xavier, denota a relevância dada à Conjuração Mineira ainda no período monárquico.

Ademais, o discurso proferido por José Pedro Xavier da Veiga no teatro Ouro-pretano na noite de 20 de abril toma considerável espaço no jornal. No discurso do político conservador foi abordada a história da Conjuração Mineira como um movimento em busca de liberdade, e que aquela teria sido a primeira vez que alguém se erguia contra a "opressão e o vilipêndio" da metrópole. Ele qualificava como patriotas os seus integrantes e diz que a

conjuração proselitisa [SIC], combina meios, improvisa recursos, distribui a cada chefe o papel que lhe cabe, traça o plano vulcânico da empresa legendária, e hasteia ao fím a bandeira do porvir, essa bandeira sagrada, em que um índio, inspirado pelo gênio das florestas, rompe cadeias seculares e desprende o brado redentor: 'Libertas quae sera tamem!' Liberdade ainda que tardia"...

No grêmio dos patriotas uma fronte eleva-se gigantesca. Desferem-lhe os olhos chispas de intrepidez, anima-lhe a palavra a febre criadora da liberdade! Sua alma religiosa, entusiástica e americana, só tem presentes duas imagens que adora: a da Trindade onipotente, no céu, e a da pátria escravizada, na terra! Invocando a primeira, ele jura consagrar à última seu heroísmo e seu sangue. Esse homem era Tiradentes - não a cabeça, mas o coração e a alma da Inconfidência - o mais ardente de seus adeptos e o primeiro de seus mártires!

\footnotetext{
${ }^{7}$ A Provincia de Minas, ano II (novo período), n. ${ }^{\circ}$ 97, 24/04/1882, Ouro Preto. P. 1. Grifos do autor. Atualizei a ortografia do texto. Grifos do autor.
} 
Os acontecimentos precipitam-se: a conjuração ia soltar o seu brado - brado terrível e augusto [...] Mas ah! Srs.! como o apostolado do Cristo, a Inconfidência teve o seu Judas, seu infame delator...

[...] a página da Inconfidência fulgura na história como um diadema de luz salpicado de sangue! [...]

Opróbrio às leis e aos juízes que fizeram verter aquele sangue e estas lágrimas! Glória aos beneméritos que as derramaram! Sangue precioso e lágrimas abençoadas [...] que cristalizaram-se na história e foram um revérbero augusto para o sol do Ipiranga! ${ }^{8}$

Esse discurso eivado de linguagem simbólica, uma linguagem que visava convencer o público que estava naquele teatro de que a Conjuração Mineira era o movimento precursor da Independência, e que por isso deveria ser enaltecido. Que era também aquele que havia legado os primeiros mártires e heróis ao panteão nacional. Certamente, boa parte daquele público conhecia a história da Inconfidência e de seus participantes por meio da tradição oral, não obstante, muitos poderiam ignorar algumas proximidades desse movimento verossímeis ou não - com a Independência brasileira. Enxergo na oratória de Xavier da Veiga um discurso político, uma mensagem que pretendia legitimar a causa dos conjurados mineiros, ou seja, buscava-se valorizar um passado nacional diferente daquele que a tradição imperial luso-brasileira promovia, em especial por aquilo que era publicado e veiculado pelo IHGB. Resta saber por que um membro do partido Conservador mineiro estaria tão interessado na memória da Inconfidência Mineira.

$\mathrm{Na}$ transcrição supracitada se nota quatro importantes situações: uma agitação emancipacionista e talvez com viés nativista; a presença de um líder carismático; a dissociação desse líder como chefe do levante; e o caráter de continuidade histórica da Conjuração Mineira com a Independência, levada a cabo em 1822.

Percebo no discurso proferido a intenção de se revelar nos conjurados um apego ao território americano, assim como uma tentativa de fazer com que aquelas figuras fossem vistas como os precursores da nação. A demonstração

\footnotetext{
${ }^{8}$ A Provincia de Minas, ano II (novo período), n. ${ }^{\circ}$ 98, 30/04/1882. Ouro Preto. P. 2 e 3. Seção Inconfidência Mineira e artigo Festa ouro-pretana. Grifos do autor.
} 
desse sentimento foi caracterizada em alguns momentos da historiografia, não apenas a brasileira, como nativismo. Rogério Forastieri da Silva (1997) comenta que a definição de movimento nativista nem sempre é precisa, assim como não tem um sentido linear atribuído pelos historiadores que se valem do termo. Silva mostra que há bastante subjetividade quando se procura qualificar um conceito como nativismo. É apontado também que muitas definições a respeito do termo podem apresentar um grande mal que aflige o historiador: o anacronismo. Visto que ao se analisar um movimento tratado como nativista e tido como prenunciador da independência, sabendo-se que esta de fato aconteceu, analisava-se um passado mais remoto a partir de um período mais recente, portanto, “constroem um 'tecido' em que estão presentes 'heróis', 'precursores', conflitos, e dá-se muitas vezes uma dimensão fora de propósito a determinados eventos com a finalidade de justificar proposições de caráter teleológico" (SILVA, 1997: 82). Porém, de todas as definições apresentadas por Silva acerca do nativismo, a que lhe parece ser a mais correta é feita por Bradford Burns, a qual diz que o nativismo no Brasil havia se dado no período colonial e com ampla identificação às coisas da terra, sem relação de oposição ao elemento português, mas como um precursor do nacionalismo.

O que se vê no discurso proferido por Xavier da Veiga naquele teatro tem um caráter similar ao que Silva (1997) dispõe, pois nele não se nota aversão aos portugueses da metrópole. ${ }^{9}$ Em seu discurso há a impressão de que os conjurados apenas bendiziam as qualidades do ser brasileiro, traço marcante nas opções de Alvarenga Peixoto pela escolha de um indígena quebrando as cadeias da opressão, e que daí se caminharia para um movimento emancipacionista.

\footnotetext{
${ }^{9}$ Coloco portugueses da metrópole, pois durante parte do período colonial brasileiro, alguns dos que aqui habitavam eram tratados como portugueses americanos. Sobre os portugueses europeus e americanos, com o intuito de tentar fortalecer a ideia de Império luso-brasileiro, "Dom Rodrigo de Sousa Coutinho pretendia que o português nascido nas quatro partes do mundo se julgue apenas português", pondo de lado os localismos, a fim de evitar dissensões dentro do Império português (MATTOS, 2005: 15). Ressaltava-se (D. Rodrigo é um bom exemplo disso) a importância em se estabelecer laços de irmandade entre os portugueses para que se atravessasse com menos dificuldade a crise política vivenciada com o esfacelamento das instituições do Antigo Regime. Temia-se que a América portuguesa, repleta de identidades coletivas, seguisse o exemplo da América espanhola e se dividisse (PIMENTA, 2007).
} 
Ainda relativamente ao discurso supracitado, nele também foi dado amplo destaque à figura de Silva Xavier, com suas qualidades elevadas: altivez, patriotismo, religiosidade, entusiasmo; tais qualificações só poderiam provir de um herói. A mensagem de Xavier da Veiga tocou nesse ponto por diversas vezes. Mas ainda que na visão desse conservador Tiradentes fosse um líder entre os conjurados, o ex-alferes dos Dragões de Minas não era "a cabeça" pensante da sublevação mineira. É bastante plausível que Tiradentes tenha tido sua liderança "intelectual" deslocada por dois fatores: primeiro por sabidamente não ser um homem de letras; segundo por ser um dos inconfidentes mais exaltados, um dos mais empolgados com o republicanismo da "revolução americana". A primeira causa é preconceituosa e tem características elitista e aristocrática, já que considera que por não ter sido um homem de estudos superiores, Tiradentes não teria tido condições de elaborar os planos para a derrubada de um governo nem mesmo de pensar um governo suplente. A segunda tem causas políticas, pois há alguns anos, sobretudo após a década de 1860, a imagem de Tiradentes passou a despertar o interesse dos segmentos simpáticos à República no Brasil. Então, a preferência dos republicanos por Silva Xavier em muito se devia ao seu caráter arrebatado e ao seu espírito entusiasmado, à sua eloquência enquanto um propugnador de um tempo novo.

Por outro lado, os interesses monarquistas deveriam se distanciar dessa via "radical" de Tiradentes. Para ser vantajosa à Monarquia, a imagem do alferes tinha que ter seu lado republicano esmaecido, deixando resplandecer sua coragem e denodo, posto que enquanto colono ele lutou contra a falta de liberdade e que por isso, era considerado "o coração e alma da inconfidência". Entretanto, o interesse em Tiradentes parava por aí, como mártir da independência e herói nacional na causa contra Portugal. Para os monarquistas, o chefe da Conjuração Mineira era ou deveria ser alguém mais graúdo, alguém que tinha muitas competências intelectuais comprovadas por seus versos líricos e diploma acadêmico, de preferência um membro da aristocracia luso-brasileira. Assim, para aqueles monarquistas, a liderança da Conjuração ficava quase 
sempre dividida entre os poetas e bacharéis Cláudio Manuel da Costa e Tomás Antônio Gonzaga.

No tocante à continuidade histórica, o proferidor do discurso no Teatro Ouro-pretano fez questão de ligar a Conjuração Mineira à Independência. Vejo nesse desejo de continuísmo referente aos dois movimentos históricos, uma lógica que punha a Conjuração como aquela que havia despertado o povo para a vontade de se libertar do autoritarismo português, enquanto que o príncipe regente Dom Pedro havia consumado aquela pretensão. Desconheço que o primeiro evento tenha tido alguma relação direta com o segundo, além do que esse tema extrapola os interesses e competências deste artigo. No entanto, vi ao longo da pesquisa que a tentativa de se relacionar ambos os movimentos não se deu poucas vezes.

A partir de outro artigo da mesma edição d'A Provincia de Minas, ressalto uma vez mais o aspecto de continuidade entre a Inconfidência e a Independência que era dado nas páginas da imprensa. Nota-se também a falta de atributos intelectuais creditada a Tiradentes:

É glorioso o dia 7 de Setembro de 1822, em que D. Pedro 1. ${ }^{\circ}$ nos campos do Ipiranga, ao receber despachos de Lisboa, levantou o majestoso grito de independência ou morte, brado este, consequência das ideias liberais que alentavam o povo brasileiro [...].

Em 1792, porém, ainda estava esta grande fonte de riquezas sob o despótico poder de uma nação, que lhe exauria todas as suas preciosidades quando surgem na heroica capitania de Minas vultos homéricos, querendo ir de encontro ao poder régio, entre os quais sobressai Joaquim José da Silva Xavier, o Tiradentes, não pela sua grande ilustração, mas pela impassível heroicidade no patíbulo [...]. ${ }^{10}$

Em finalização desta edição do jornal Conservador foi publicado um soneto em homenagem à Tiradentes e que foi pronunciado no Teatro Ouropretano na noite de 22 de abril.

Mas tanto nas páginas d'A Provincia de Minas quanto nas do Liberal Mineiro, de forma mais detalhada neste, foram registrados anúncios que diziam respeito à formação de uma comissão para se proceder à organização das

\footnotetext{
${ }^{10}$ A Provincia de Minas, ano II (novo período), n. ${ }^{\circ}$ 98, 30/04/1882. Ouro Preto. P. 3 e 4. Seção Comunicados e artigo Tiradentes, assinado por F. Amaral, de São Paulo.
} 
cerimônias que propunham homenagear o inconfidente Tiradentes. Vê-se que n'A Provincia de Minas uma "comissão popular" foi formada com a finalidade de organizar o evento. ${ }^{11}$ Não se mencionava cor partidária dessa comissão nem mesmo tacitamente. Já no Liberal Mineiro se dava ampla divulgação da intenção de algumas pessoas em formar um grupo que organizaria os ditos festejos.

No sentido de dar publicidade à necessidade de se criar um grupo que procederia às celebrações a Tiradentes em abril de 1882, o Liberal Mineiro disponibilizou notícias em suas páginas que abrangeram o mês de fevereiro daquele ano, do número 13 ao 17. Anunciava-se que "São convidados todos os cidadãos residentes nesta capital a comparecerem no Teatro Ouro-pretano, ao meio dia de 12 do corrente, para deliberar-se sobre os festejos do $9 .^{\circ}$ decenário de Tiradentes, o protomártir da independência do Brasil". ${ }^{12}$ Mesmo as edições 15 e 16, que foram publicadas após o dia 12 de fevereiro, mantiveram o anúncio, certamente porque deveria haver um número mínimo de dias em que um anúncio era publicado nas páginas do jornal, e tal número extrapolou o dia da pretendida reunião.

Ainda sobre a formação daquela comissão, parece-me que as solenidades a Tiradentes poderiam causar algum inconveniente, talvez pelo conhecido republicanismo do homenageado, sendo que se vivia sob uma monarquia. Provavelmente seja por isso que a comissão convidava todas as classes sociais para participar dos eventos, pois se grande quantidade de pessoas comparecesse às festas, tais comemorações se justificariam. Assim,

Efetuou-se no teatro ouro-pretano, no dia 12 do corrente, a reunião de diversos cidadãos, para a qual haviam sido previamente convidados, a fim de deliberar-se sobre os festejos do $9 .^{\circ}$ decenário de Tiradentes, o protomártir da Independência do Brasil.

Ficou assentada a nomeação de uma comissão central [...]

Esta distinta comissão, segundo nos consta, dirigir-se-á a todas as classes de cidadãos da capital, funcionários públicos, ativos e aposentados, clérigos, magistrados, funcionários do foro, oficiais militares, corpo docente e acadêmico de

\footnotetext{
${ }^{11}$ A Provincia de Minas, ano II (novo período), n. ${ }^{\circ} 96,16 / 04 / 1882$. Ouro Preto. P. 1 e 4.

${ }^{12}$ Edições 13 a 17 do ano V do Liberal Mineiro. Ouro Preto.
} 
instrução primária, secundária e superior, comércio, artes, indústrias e ofícios, competentemente representados por comissões parciais, solicitando de todos o indispensável e patriótico concurso para o bom êxito de sua tarefa.

O Ouro Preto, antiga e heroica Vila Rica, onde primeiro se levantou o brado da - Liberdade -; que esconde por entre suas montanhas a invejável união de seus pacíficos e ordeiros habitantes, não ficará mal, estamos certos, nas circunstâncias presentes, em que se trata de solenizar o fato mais patriótico de nossa vida política. ${ }^{13}$

Além desta mensagem ao povo ouro-pretano, ou à parte liberal que lia o jornal, que enfatizava a importância da presença do público nas cerimônias, fezse um "Convite" para que os alunos dos cursos de Farmácia, da Escola de Minas, e dos preparatórios se fizessem presentes ao Teatro Ouro-pretano no dia 19 de fevereiro para deliberarem sobre os festejos ao $9 .^{\circ}$ decenário de Tiradentes. ${ }^{14}$ Isto é, a comissão central responsável por organizar o evento necessitava de legitimação popular para que não houvesse quaisquer problemas junto aos governos imperial e Provincial.

Ainda que uma comissão de cidadãos interessados em organizar alguns eventos que homenageassem Joaquim José da Silva Xavier tenha sido formada, algo mais que a dedicação dessas pessoas era imprescindível: dinheiro. Recursos financeiros eram necessários para se conseguir o espaço do Teatro Ouro-pretano, para enfeitar a Praça da Independência e outras vias, bem como para a compra de fogos de artifício e balões, além de outros gastos. Ao se analisar o Liberal Mineiro dá-se conta que a comissão central teve que buscar meios para angariar fundos para a realização do $9 .^{\circ}$ decenário de Tiradentes. Fizeram um anúncio nesse jornal com o intuito de divulgarem duas peças teatrais que aconteceriam no Teatro Ouro-pretano. Ambas seriam realizadas em 18 de março de 1882 e teriam como fim a arrecadação de dinheiro. ${ }^{15}$

\footnotetext{
${ }^{13}$ Liberal Mineiro, ano V, n. ${ }^{\circ}$ 17, 16/02/1882. Ouro Preto. P. 2. Seção Noticiário e artigo Nono decenário de Tiradentes. Grifos meus.

${ }^{14}$ Liberal Mineiro, ano V, n. ${ }^{\circ}$ 17, 16/02/1882. Ouro Preto. P. 3. Seção: Seção Livre e artigo Convite.

${ }^{15}$ Edições 24 a 28 do ano V do Liberal Mineiro. Ouro Preto.
} 
Entretanto, as apresentações teatrais que aconteceriam naquele dia, mas que aparentemente se deram em 22 de março, ${ }^{16}$ parecem não ter sido suficientes para prover a comissão central do dinheiro necessário para as celebrações de abril vindouro. Pois abaixo do anúncio da programação feita n'A Provincia de Minas acerca da louvação pública a Tiradentes postou-se uma nota em que a comissão pedia a colaboração do público. Desse modo,

A comissão central, contando com escassos recursos para ocorrer às enormes despesas que foi forçada a fazer para comemorar tão importante acontecimento [...] espera toda a animação e a maior concorrência possível aos dois espetáculos, cujo produto tem de ser aplicado às ditas despesas. ${ }^{17}$

Após a redação do Liberal Mineiro fazer bastante divulgação relativa à comissão central, foram laboradas algumas edições em que abordaram as festas propriamente ditas. São exatamente seis o número de publicações que diziam respeito aos aspectos da Conjuração Mineira e aos 90 anos da morte de Tiradentes. Inclusive, uma edição especial saiu dia 21 de abril de 1882 e tratou apenas de fatores ligados à Inconfidência. A comissão central aproveitou o ensejo do júbilo a Tiradentes e incluiu uma homenagem ao liberal histórico Teófilo Otoni, cujo filho homônimo ocupava a presidência mineira àquele tempo. Enfim, tal comissão pareceu ter feito grande esforço para organizar uma grandiosa homenagem e com ampla programação artística. Eis as programações das peças musicais que seriam apresentadas nas noites dos dias 20 e 22 de abril daquele ano:

No lugar competente estampamos hoje o programa organizado pela comissão central encarregada dos festejos do 9. ${ }^{\circ}$ decenário de Tiradentes [...]

As peças musicais, que o excelente coro - Henrique Mesquita - escolheu entre o seu repertório para executar nas noites de 20 e 22 do corrente, são as seguintes:

Sonho da Independência - overtura [sic] de Emílio Horta para grande orquestra.

Hino da Independência - do mesmo autor - a solo, coros e orquestra; peça consagrada à memória de Teófilo Otoni.

Overturas [sic] pela orquestra. [...]

${ }^{16}$ Liberal Mineiro, ano V, n. ${ }^{\circ}$ 30, 23/03/1882. Ouro Preto. Seção Anúncios e artigo Teatro Ouro-pretano.

${ }^{17}$ A Provincia de Minas, ano II (novo período), n. ${ }^{\circ}$ 96, 16/04/1882. Ouro Preto. P. 4. 
Concerto de Wilhelm Popp, executado no pistão por Oscar Bessa.

Pot-pourri concertante para duas clarinetas, de André Spaeth, executado pelos irmãos Fernando e Francisco Moreira.

Esta última peça, que foi executada no ano passado do festival oferecido a SS. MM. Imperiais no paço da assembleia provincial [...]

São dignos de toda a animação por parte da sociedade ouropretana os esforços que emprega a distinta comissão central para desempenhar-se de tão nobre e patriótico cometimento. ${ }^{18}$

Um pouco adiante no jornal há ainda mais três anúncios relativos às festas do 9. ${ }^{\circ}$ decenário de morte de Tiradentes. O primeiro deles dizia respeito ao programa elaborado pela União Escolástica com o fito de homenagear o inconfidente supliciado pela Coroa portuguesa. A programação previa uma marche aux flambeaux a partir do Liceu Mineiro, às 18h, percorrendo algumas ruas e em visita a locais históricos da Inconfidência. Discursos seriam proferidos e uma coroa de louros seria posta perante o quadro dos inconfidentes que se encontrava no palácio da presidência da Província. ${ }^{19} \mathrm{O}$ curto e segundo anúncio era de uma propaganda em que os festejos em memória a Tiradentes eram utilizados como um chamamento. Já o terceiro constava da programação oficial onde havia o cronograma para os dias 20, 21 e 22.

Assim, no dia 20, o presidente da Província estaria presente ao evento em que orquestra e coro executariam as peças Sonho da Independência e o Hino de Tiradentes. Seguir-se-ia a alguns discursos uma "apoteose ao protomártir da independência" e a representação do drama Abençoadas lágrimas. Dia 21 haveria tiros de salva e a execução do Hino de Tiradentes pela banda marcial do corpo policial, que percorreria algumas ruas da cidade. No teatro teria lugar uma conferência literária sobre os principais personagens da Conjuração Mineira. Mais tarde, o jardim da praça seria iluminado e haveria nova execução do Hino de Tiradentes, seguido por algumas músicas tocadas pela banda do

\footnotetext{
${ }^{18}$ Liberal Mineiro, ano V, n. ${ }^{\circ}$ 39, 18/04/1882. Ouro Preto. p. 4. Seção Noticiário e artigo 9. ${ }^{\circ}$ decenário de Tiradentes.

${ }^{19}$ Acredito que o quadro em questão seja o que foi pintado por Leopoldino J. de Faria e que esteve exposto na Corte e na capital mineira entre fins da década de 1870 e inícios da de 1880, e que retratava os conjurados mineiros.
} 
corpo policial, bem como por fogos de artifícios e balões. Além de existir uma tribuna na praça para quem quisesse discursar. Enquanto que dia 22 aconteceria uma abertura feita por senhoras que cantariam a peça Sonho da Independência. Antes da apoteose, alguns membros da comissão organizadora tomariam a palavra. Logo após se daria nova exibição do drama teatral apresentado no primeiro dia de evento. Nos intervalos dessa peça, como também nos do dia 20 , o coro Henrique Mesquita executaria "as melhores overturas [sic] e concertos". 20

Porém, existem mais detalhes importantes. Exatamente abaixo da programação oficial publicou-se um comunicado igual ao que saiu nas páginas d'A Provincia de Minas de 16 de abril. O informe fazia referência às dificuldades financeiras encontradas pela comissão central em organizar as celebrações. No entanto, naquela edição de 18 de abril do Liberal Mineiro, o comunicado foi um pouco mais abrangente: "Desde já [a comissão central] previne também que não há venda de boletos na porta do teatro, havendo exceções quanto ao ingresso só para as pessoas de fora da cidade, que venham assistir a representação do drama". ${ }^{21}$

Portanto, percebe-se que foi promovido um tipo de venda de bilhetes, os boletos, que davam direito de acesso a mais de um evento pago, talvez para as peças teatrais das noites de 20 e 22 que ocorreriam no Teatro Ouro-pretano. No entanto, sem fazer mais menções aos conjurados mineiros nessa edição, foi no dia 21 de abril publicado um número especial dedicado inteiramente a Tiradentes, cujo título, logo abaixo do nome do jornal e com bastante destaque, dava conta da "Comemoração do $90 .^{\circ}$ aniversário da execução de Tiradentes". As quatro páginas dessa edição foram enfeitadas com bordados nas extremidades, e embora fosse uma edição do Liberal Mineiro, talvez por ser extraordinária, não teve inserido o número (edição) nem o ano.

Assim sendo, a capa desse jornal apresentava de maneira muito destacada o hino de Tiradentes, escrito pelo famoso poeta mineiro Bernardo

\footnotetext{
${ }^{20}$ Liberal Mineiro, ano V, n. ${ }^{\circ} 39,18 / 04 / 1882$. Ouro Preto. p. 4. Seção Anúncios.

${ }^{21}$ Liberal Mineiro, ano V, n. ${ }^{\circ}$ 39, 18/04/1882. Ouro Preto. p. 4. Seção Anúncios.
} 
Guimarães. É digno de nota acenar para o fato de que Guimarães estabelecia relações da Inconfidência Mineira com a Independência, acrescentando que o movimento mineiro ansiava por liberdade e independência, como se vê: "De teu sangue generoso. / Esta terra rociada / Fez brotar da independência / A semente abençoada. / [...] Esse sangue derramado / Pelo brutal despotismo / Foi da pátria brasileira / O sacrossanto batismo." ${ }^{22}$ A capa desta edição extraordinária em memória de Tiradentes pode ser vista nas imagens abaixo.

Imagem 1- Fotografia feita a partir de edição do Liberal Mineiro

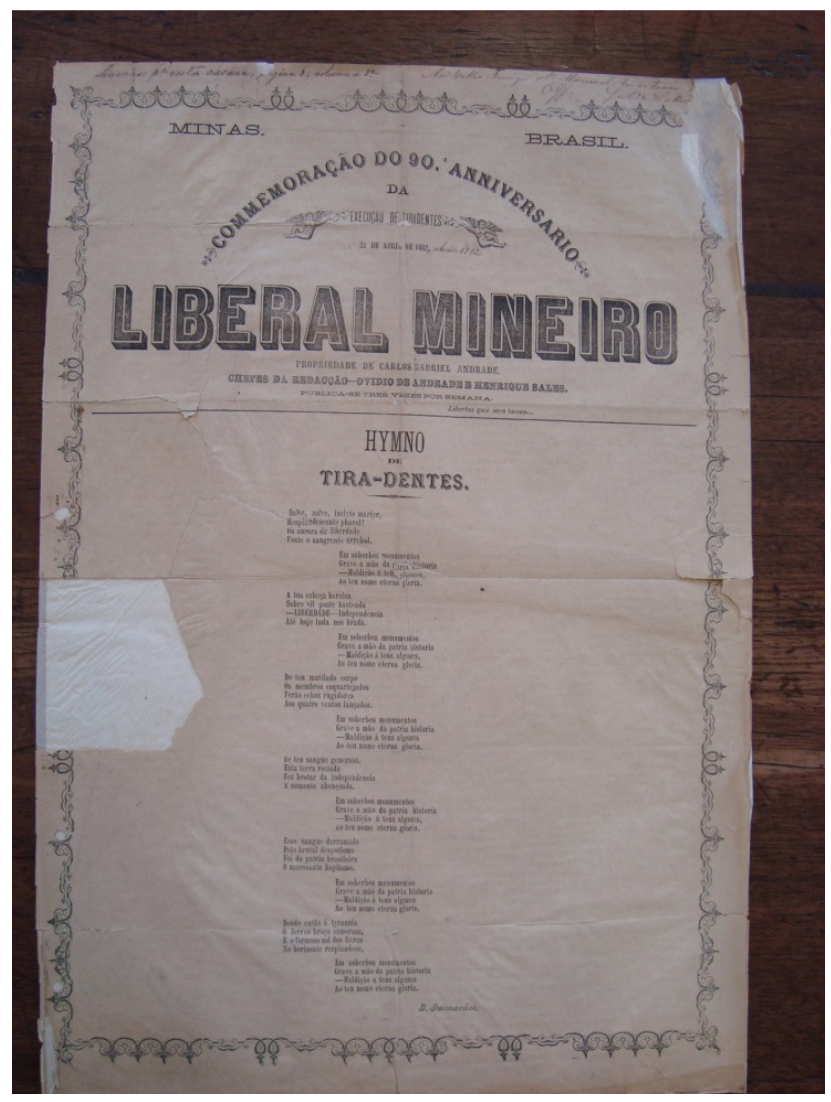

Fonte: Arquivo Museu Casa do Pilar, Ouro Preto.

\footnotetext{
${ }^{22}$ Liberal Mineiro, edição extraordinária, 21/04/1882. Ouro Preto. p. 1.
} 
Imagem 2 - Fotografia aproximada da imagem 1, Liberal Mineiro

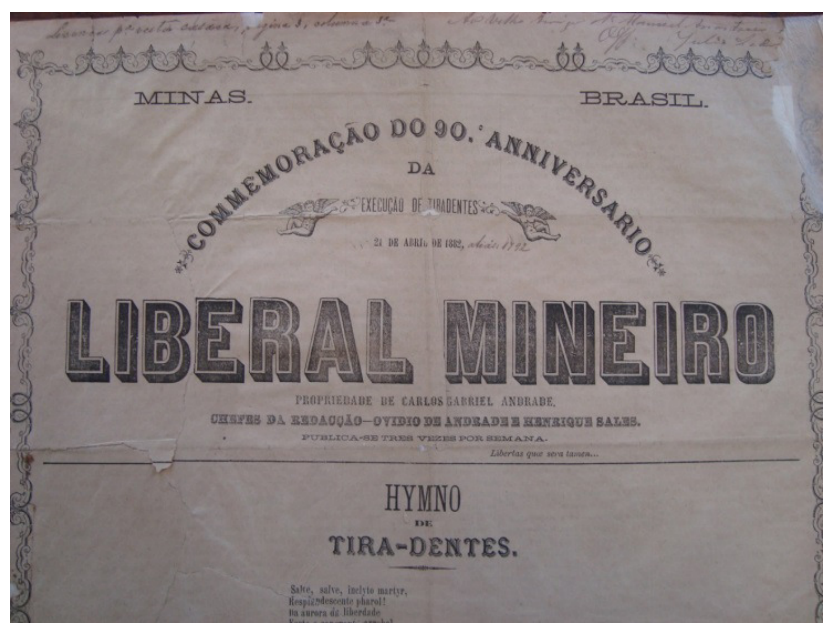

Fonte: Arquivo Museu Casa do Pilar, Ouro Preto.

Ademais, em artigo sem assinatura, provavelmente por se tratar do editorial - embora não esteja especificado -, tratou-se da memória de Joaquim José da Silva Xavier. Falou-se de sua liderança na Conjuração Mineira e de ter sido o precursor da liberdade brasileira. Assim,

Já lá se vão noventa anos que de uma forca, levantada no antigo largo de S. Domingos da cidade do Rio de Janeiro, pendeu exânime o corpo do primeiro mártir de nossa independência.

Já lá se vão noventa anos que, por ordem dos juízes da alçada, dignos esbirros do despotismo colonial, foi decepada pelo ferro do algoz a nobre e altiva cabeça, que cometera o monstruoso atentado de sonhar com a liberdade da pátria.

Esquartejaram-no, dispersaram-lhe os membros sanguinolentos pelas estradas e praças públicas, arrasaramlhe a casa, salgaram o terreno e mandaram levantar aí um padrão de infâmia, que atestasse aos vindouros a enormidade do crime e a grandeza da repressão.

Entretanto, após noventa anos decorridos, vive ainda na memória agradecida do povo o nome querido do Tiradentes; é ainda a sombra veneranda do glorioso precursor que preside as festas da liberdade nesta terra da América.

Debalde empenharam-se as justiças portuguesas por votar à execração da posteridade o nome e os feitos do legendário mártir:

Debalde empenham-se ainda hoje por amesquinhar-lhe a gigantesca estatura historiadores sem fé, que deturpam com igual desamor a verdade histórica e as glórias da pátria: 
A figura heroica do destemido mineiro vai avultando através dos anos, e já se apresenta à imaginação popular com as irradiações combinadas da liberdade e do martírio.

É que Tiradentes foi o verdadeiro chefe da conjuração mineira malograda em 1789.

Foi ele quem primeiro sonhou com a nossa emancipação política $[\ldots]^{23}$

Ainda que monarquista, o autor deste artigo não temeu creditar à Tiradentes a liderança da Inconfidência, atitude muito comum entre seus adversários republicanos. Certamente ele o escreveu com o fito de contestar "os historiadores" contemporâneos, além de tencionar laurear a figura de Tiradentes. Acredito que o desafeto nesse ponto, de pretender elevar a imagem de Silva Xavier, era Joaquim Norberto de Sousa e Silva, que em 1873 lançou um livro que narrava a história da Conjuração Mineira a partir dos Autos da Devassa da Inconfidência Mineira. ${ }^{24}$ Era um trabalho inédito até aquele momento no que dizia respeito às fontes da Inconfidência, posto que outros historiadores se valiam, em geral, apenas da sentença da Alçada.

Mesmo com algumas partes rasgadas dessa edição vê-se que há em todas as páginas apenas lugar para artigos com a intenção de bendizer Tiradentes. Em sua maioria, os artigos faziam a relação de sua figura com a tentativa de tornar o Brasil um país livre. A correlação de Tiradentes com a Independência, e de sua suposta intenção em transformar a colônia portuguesa na América em um território livre de Portugal, visava afastar da Conjuração Mineira um possível caráter de movimento separatista. Isto era necessário porque apenas pelo conhecimento que se tinha das fontes da Conjuração não era possível depreender que se levada às últimas consequências, os membros da insurreição tentariam congregar mais territórios que os das Capitanias do Rio de Janeiro e São Paulo (em alguns relatos, essa junção era almejada), contíguas a Minas Gerais, e também próximas em relação ao passado colonial. Aliás, nem mesmo a possibilidade dessas Capitanias tomarem parte num movimento independentista em apoio aos inconfidentes era palpável, embora aventada.

\footnotetext{
${ }^{23}$ Liberal Mineiro, edição extraordinária, 21/04/1882. Ouro Preto. P. 2. Artigo Tiradentes.

${ }^{24} \mathrm{O}$ livro era a História da Conjuração Mineira, e nos anos subsequentes à sua publicação, ele e seu autor foram alvo de muitas críticas, pois se acreditava que Sousa e Silva teve a intenção de denegrir a imagem de Tiradentes em função do fortalecimento do republicanismo no Brasil.
} 
Em um artigo de natureza bastante alegórica, embora não fosse um conteúdo inédito, Silva Xavier era comparado com personagens bíblicos. Neste caso, Tiradentes foi equiparado a Cristo e a Moisés como aquele que mostrou o caminho da liberdade para os brasileiros: "Ele foi-nos o Messias desta nova lei revelada: - A Liberdade! Ele foi Moisés apontando-nos de longe a terra da promissão [...]". ${ }^{25}$ Além do título do artigo também é interessante observar como era feito um paralelo entre o passado e o futuro. A tradição cristã e um movimento em busca de um tempo que estava por vir. Desta maneira, com o conhecimento do passado, a experiência apontava para um futuro mais promissor, de modo que havia um horizonte de expectativas favorável àqueles brasileiros.

Igualmente, deparei-me nessa edição com alguns artigos que tratavam da inspiração que a revolução das 13 colônias inglesas da América do Norte provocava em parte dos conjurados mineiros, mas principalmente em Joaquim José da Silva Xavier. E aqueles que citavam sua inteligência, abnegação e liderança. Bem como abordava-se novamente o livro de Joaquim Norberto de Sousa e Silva, que seria parcial e com pretensões de denegrir a Inconfidência Mineira, e em especial a memória de Tiradentes. ${ }^{26}$

Já na edição subsequente a essa de 21 de abril publicou-se algumas impressões causadas acerca dos festejos a Tiradentes. Assim, no principal artigo do Liberal Mineiro referente àqueles, foi passada a impressão do autor, o qual fez questão de dar destaque ao público presente aos locais das celebrações, assim como aos detalhes promovidos pela comissão organizadora e que fizeram daqueles dias festivos, dias diferenciados para a capital mineira.
A comissão, promotora das solenidades comemorativas do 9. ${ }^{\circ}$ decenário de Tiradentes, perfeita e magnificamente soube desempenhar-se de sua árdua e nobilíssima tarefa.
$\mathrm{O}$ programa anunciado verificou-se com a mais esmerada execução em todas as suas minúcias.
Às prestantes corporações escolásticas, em boa parte, também é devido o complemento desta brilhante festa patriótica.

\footnotetext{
${ }^{25}$ Liberal Mineiro, edição extraordinária, 21/04/1882. Ouro Preto. P. 2. Artigo $O$ passado e o porvir.

${ }^{26}$ Liberal Mineiro, edição extraordinária, 21/04/1882. Ouro Preto. P. 3 e 4.
} 
A procissão cívica, que inauguraram [SIC], em visita aos lugares históricos da conjuração mineira, hasteando à sua frente o pendão simbólico da inconfidência [...] foi seguramente, de entre todas as manifestações populares, a mais significativa, a mais legítima, a mais elevada. [...]

O teatro, durante duas noites, foi o centro da concorrência pública; as frisas e a plateia transbordaram de espectadores [...]

O largo da praça da Independência oferecia anteontem a noite um aspecto curiosíssimo, uma perspectiva mirífica!

Cinco mil globos e lanternas multiformes e multicores, suspensos dos festões de flores, dos esgalhos das árvores, das colunas, dos arcos triunfais, de todos os edifícios em torno, difundia, em inúmeras cintilações iriadas, em miríadas d'estrelas, um albor crepuscular, fosco, denso; pelos recantos e devezas [SIC] do jardim todas as proezas dos jogos pirotécnicos foram aí postos em ação. Os fogos de bengala, as girândolas, fuzilavam a trechos, vibrando em mil curvas e ziguezagues mil raios de luz. [...]

O povo premava-se numa mole tremenda, compacta festivo, jubiloso, bulhento. E todavia, nem um só conflito, nem um único distúrbio! $!^{27}$

Uma interessante associação foi feita num artigo relativo a inauguração do trecho ferroviário que ligaria Ouro Preto à Estrada de Ferro Dom Pedro II. O autor se referia àquela inauguração, feita em 21 de abril de 1882, como sendo proposital e significativa, pois "ocorrer este ato no mesmo dia, em que a antiga Vila Rica revestia todas as suas galas para prosseguir na celebração das festas do 9. ${ }^{\circ}$ decenário do seu primeiro herói". ${ }^{28}$ Pelas palavras do autor vê-se que já naquele período havia tentativas de se criar datas simbólicas e lugares de memória.

A seguir foi publicado um extenso artigo onde um cidadão, talvez um assinante do Liberal Mineiro, pormenorizou as celebrações aos inconfidentes. Nesse texto foi dito que foram quatro dias de festas organizados pela comissão central, e não três como se vê em todos os outros. Ainda assim percebe-se algumas intenções do texto, como transmitir ao leitor que as cerimônias tiveram um caráter oficial, denotado pela presença do presidente da Província, sua

\footnotetext{
${ }^{27}$ Liberal Mineiro, ano V, n. ${ }^{\circ} 40,25 / 04 / 1882$. Ouro Preto. p. 3. Seção Noticiário e artigo Festejos do 9. ${ }^{\circ}$ decenário de Tiradentes.

${ }^{28}$ Liberal Mineiro, ano V, n. ${ }^{\circ} 40,25 / 04 / 1882$. Ouro Preto. p. 3. Seção Noticiário e artigo Via férrea ouro-pretana.
} 
esposa, e de instituições escolásticas ouro-pretanas; e que houve ampla participação popular.

À noite, a briosa classe escolástica, que para comemorar a gloriosa data de 21 de Abril, estabelecera a - União Escolástica - dos estudantes da escola de minas, liceu e escola normal, veio tomar de espanto e comoção a população, apresentando a mais bela e imponente manifestação à memória dos inconfidentes! [...]

Eloquente manifestação, admirável devotamento da mocidade $[\ldots]$

Precedidos por uma banda de música, guiados por um bem acabado estandarte de cetim cor de rosa, em cujas dobras liase Libertas quae sera tamem, uns 300 moços empunhando lanternas de apurado gosto e ladeados pelo nobre povo admirado e comovido, caminhavam na mais perfeita ordem e com o mais respeitoso silêncio, fazendo guarda de honra a 10 graciosas meninas, que conduziam, em uma grande salva de prata, a coroa de louros, destinada ao quadro da Inconfidência colocado no palácio do governo.

[...] Aí, perante S. Ex. ${ }^{a}$ o Sr. Dr. Teófilo Otoni e sua Exma. Sr. $^{a}$ e escolhido concurso de cavalheiros e Sras., depois de ter o préstito feito alto em frente ao quadro $\left[. . .{ }^{29}{ }^{29}\right.$

Ainda de acordo com o autor da notícia, a Praça da Independência teve público estimado em cerca de quatro mil espectadores no último dia das celebrações. Além de detalhar que havia 24 lanternas junto às colunas na dita praça e que em cada uma dessas lanternas estava escrito o nome de um conjurado.

Não obstante essas três edições seguidas do Liberal Mineiro - de números 39, 40 e a edição extraordinária - darem bastante destaque à Conjuração Mineira e a Joaquim José da Silva Xavier, a publicação de número 41 ainda deu espaço a duas notícias que acrescentaram mais detalhes às ditas festas. A primeira delas era do próprio jornal e dizia que pela pressa em se escrever e publicar o jornal algumas minúcias dos dias de comemoração foram esquecidos. A segunda dizia respeito à união escolástica ouro-pretana. Agradeceu-se em nome desta às pessoas que ajudaram na organização das festas, ao público que compareceu às cerimônias e aos pais que permitiram que

\footnotetext{
${ }^{29}$ Liberal Mineiro, ano V, n. ${ }^{\circ} 40,25 / 04 / 1882$. Ouro Preto. p. 3 e 4, seção Comunicado e artigo Os gloriosos dias consagrados a honrar o 9..$^{\circ}$ decenário dos mártires da Inconfidência Mineira. Grifos do autor.
} 
suas filhas desfilassem pelas ruas de Ouro Preto com a coroa que ornamentaria o quadro dos inconfidentes. ${ }^{30}$

Mesmo que os dias de festas e homenagens aos conjurados mineiros tivessem passado, por parte de algumas pessoas houve o interesse de dar prosseguimento à comissão central, a comissão que juntamente com a união escolástica idealizou aqueles festejos. Assim, em notícia publicada no Liberal Mineiro ficou marcada uma reunião para 30 de abril de 1882, no Teatro Ouropretano, com o intuito de que "cidadãos patriotas" consentissem em criar um clube que passaria a organizar as celebrações a Tiradentes em todos os anos dali por diante. ${ }^{31}$ No entanto, nas edições seguintes não se publicou mais nenhuma notícia relativa à dita reunião popular nem mesmo foi dito se o pretendido clube foi fundado. Vê-se no correr do texto que aquele tencionado clube parece não ter logrado êxito, pois não vi mais nenhuma menção a ele. Assim como as comemorações a Tiradentes e aos demais conjurados, que a partir daquele momento deram-se em muito menor escala que as que ocorreram em Ouro Preto em 1882.

$\mathrm{O}$ ano de 1882 foi um período ímpar em Minas Gerais devido ao alto relevo que foi dado à Conjuração Mineira, e essencialmente à imagem de Joaquim José da Silva Xavier, com amplo destaque à sua memória. Afinal de contas houve uma programação repleta de atividades, com três dias de festas, discursos enaltecedores, conferências, etc. na capital mineira; dias em que a memória inconfidente e o orgulho mineiro foram elevados de um modo que se demonstrava que havia bastante interesse em se recuperar a Inconfidência Mineira como um evento de destaque na história nacional.

Contudo, o ano seguinte d'A Provincia de Minas mostra que foi tímida a programação de consagração à Conjuração. Aparentemente só se deu destaque a Tiradentes, o mais exaltado dentre os conjurados, e diferentemente de 1882 só se procedeu a uma conferência em tributo de sua imagem. Não se sabe se a

\footnotetext{
${ }^{30}$ Liberal Mineiro, ano V, n. ${ }^{o}$ 41, 27/04/1882. Ouro Preto. p. 3. Seção: Seção livre; artigos: Tiradentes; e Festejos populares.

${ }^{31}$ Liberal Mineiro, ano V, n. ${ }^{\circ} 42,29 / 04 / 1882$. Ouro Preto. p. 5. Seção Noticiário e artigo Reunião popular.
} 
comissão organizadora dos festejos de 1882 se desintegrou, se o clube planejado para aquele fim fracassou, ou se as dificuldades financeiras para se proceder a outro evento como o de 1882 se fizeram valer. Assim sendo, na capa da edição de 23 de abril de 1883 foi feita uma "Homenagem a Tiradentes" pelo dia de seu padecimento em prol da liberdade brasileira:

O dia de anteontem, 21 de Abril, 91. ${ }^{\circ}$ aniversário da execução de Joaquim José da Silva Xavier, não passou de todo desapercebido [SIC] nesta capital.

A convite do inteligente professor do Liceu mineiro, Sr. Eduardo Machado de Castro, reuniu-se à noite considerável número de cidadãos de todas as classes no teatro ouropretano, e aí o mesmo Sr. Machado fez uma conferência sobre o glorioso protomártir da independência nacional, discutindo diversas opiniões de escritores que se têm ecupado [SIC] da conjuração mineira de 1789.

Ao conclunir [SIC] seu discurso, foi o orador geralmente aplaudido. ${ }^{32}$

Fica novamente evidenciada a tentativa de se correlacionar a Inconfidência com a Independência. E exatamente como foi feito nas comemorações de abril de 1882, tentou-se passar a impressão de que pessoas de todas as classes sociais compareceram ao evento de homenagem ao mártir, talvez com o objetivo de se legitimar, uma vez mais, a reunião e o preito a Tiradentes.

Com este artigo eu quis demostrar um breve posicionamento de dois jornais acerca de Tiradentes e das comemorações em sua memória em um ano em que esta recebeu considerável destaque: os monarquistas Liberal Mineiro e A Provincia de Minas demonstram que para o ano de 1882, principalmente, um farto material foi preparado com o propósito de promover a derradeira conciliação entre o regime monárquico e o imaginário inconfidente (na baila do republicanismo). Essa tentativa de apaziguamento entre o regime representado pelos jornais partidários e pela comissão organizadora - e a memória da Inconfidência certamente passava por um cálculo meticuloso dos monarquistas e que envolvia ícones do passado nacional que poderiam e deveriam ajudar a resguardar o governo imperial contra a onda republicana.

\footnotetext{
${ }^{32}$ A Provincia de Minas, ano III, n. ${ }^{\circ} 149,23 / 04 / 1883$. Ouro Preto. p. 1. Grifos do redator.
} 


\section{Referências}

ALONSO, A. Idéias em movimento: a geração 1870 na crise do Brasil-Império. São Paulo: Paz e Terra, 2002.

CARVALHO, J. M. de. A formação das almas: o imaginário da República no Brasil. São Paulo: Companhia das Letras, 11. ${ }^{a}$ reimpressão, 2001.

CARVALHO, J. M. de. Radicalismo e republicanismo. In: CARVALHO, J. M. de; NEVES, L. M. B. P. das (Orgs.). Repensando o Brasil do Oitocentos: cidadania, política e liberdade. Rio de Janeiro: Civilização Brasileira, 2009. P. $19-48$.

FURTADO, J. P. O manto de Penélope: história, mito e memória da Inconfidência Mineira de 1788-9. São Paulo: Cia. das Letras, 2002.

MARTINS, A. L. Imprensa em tempos de Império. In: MARTINS, A. L.; LUCA, T. R. de (Orgs.). História da imprensa no Brasil. 2. edição. São Paulo: Contexto, 2012. P. 45-80.

MATTOS, I. R. de. Construtores e herdeiros: a trama dos interesses na construção da unidade política. Almanack Brasiliense, São Paulo, n. 1, p. 8-26, 2005.

MAXWELL, K. A devassa da devassa: a Inconfidência Mineira, Brasil Portugal, 1750-1808. 2. ${ }^{\mathrm{a}}$ ed. Rio de Janeiro: Paz e Terra, 1978.

MOREL, M. Os primeiros passos da palavra impressa. In: MARTINS, A. L.; LUCA, T. R. de (Orgs.). História da imprensa no Brasil. 2. ${ }^{\mathrm{a}}$ ed. 1. ${ }^{\mathrm{a}}$ reimpressão. São Paulo: Contexto, 2012. P. 23-43.

PIMENTA, J. P. G. Brasil y las independencias de Hispanoamérica. Castelló de la Plana: Publicacions de la Universitat Jaume I, D.L., 2007.

RICUPERO, R. O Brasil no mundo. In: SCHWARCZ, L. M. (Dir.). História do Brasil nação: 1808-2010. Volume 1: Crise colonial e independência: 18081830. Objetiva: Rio de Janeiro, 2011.

SILVA, R. F. Colônia e nativismo: a História como "biografia da nação". Editora Hucitec, São Paulo, 1997.

Fontes

A Provincia de Minas. Jornal publicado de 1878 a novembro de 1889.

Liberal Mineiro. Jornal editado de janeiro de 1882 a 1889.

Recebido em: 8 de setembro de 2019

Aceito em: 28 de fevereiro de 2020 